\title{
Correction to: Nationwide system to centralize decisions around ECMO use for severe COVID-19 pneumonia in Japan (Special Correspondence)
}

\author{
Japan ECMOnet for COVID-19
}

\section{Correction to: J Intensive Care (2020) 8:29 https://doi.org/10.1186/s40560-020-00445-4}

In the original publication of this article [1], an error was found in the collaborator name Japan ECMOnet for COVID-19.

The incorrect author name is: Japan ECMsOnet for COVID-19.

The correct author name is: Japan ECMOnet for COVID-19.

Published online: 25 May 2020

\section{Reference}

1. Japan ECMsOnet for COVID-19. Nationwide system to centralize decisions

around ECMO use for severe COVID-19 pneumonia in Japan (Special

Correspondence). J Intensive Care. 2020;8:29.

\footnotetext{
The original article can be found online at https://doi.org/10.1186/s40560020-00445-4.

Correspondence: shinhiro@nms.ac.jp

Japan ECMOnet for COVID-19 Japanese Society of Intensive Care Medicine, the Japanese Association for Acute Medicine, the Japanese Society of Respiratory Care Medicine, and the Japanese Society of PCPS/ECMOhttps:// jintensivecare.biomedcentral.com/articles/10.1 186/s40560-020-00440-9
}

(c) The Author(s). 2020 Open Access This article is licensed under a Creative Commons Attribution 4.0 International License, which permits use, sharing, adaptation, distribution and reproduction in any medium or format, as long as you give appropriate credit to the original author(s) and the source, provide a link to the Creative Commons licence, and indicate if changes were made. The images or other third party material in this article are included in the article's Creative Commons licence, unless indicated otherwise in a credit line to the material. If material is not included in the article's Creative Commons licence and your intended use is not permitted by statutory regulation or exceeds the permitted use, you will need to obtain permission directly from the copyright holder. To view a copy of this licence, visit http://creativecommons.org/licenses/by/4.0/ The Creative Commons Public Domain Dedication waiver (http://creativecommons.org/publicdomain/zero/1.0/) applies to the data made available in this article, unless otherwise stated in a credit line to the data. 